\title{
Effect of Administration of Combination of Captopril and Celery Extract on Blood Pressure and Electrolyte Levels of Hypertensive Rats
}

\author{
Siska Siska ${ }^{1 *}$, Franciscus D. Suyatna ${ }^{2}$, Abdul Mun `im³ ${ }^{3}$, dan Anton Bahtiar ${ }^{3}$ \\ ${ }^{1}$ Departemen Farmakologi, Fakultas Farmasi dan Sains, Universitas Muhammadiyah Prof. Dr. HAMKA, Indonesia \\ ${ }^{2}$ Departemen Farmakologi dan Toksikologi, Fakultas Kedokteran, Universitas Indonesia, Indonesia \\ ${ }^{3}$ Fakultas Farmasi, Universitas Indonesia, Jawa Barat, Indonesia
}

Submitted 27 March 2020; Revised 11 April 2020; Accepted 13 April 2020; Published 30 October 2020

*Corresponding author: siska@uhamka.ac.id

\begin{abstract}
Based on previous reports, the combination of captopril and celery could reduce blood pressure in hypertensive patients. This study aimed to investigate the changes of blood pressure, urine volume, sodium, and potassium level, due to concomitant administration of captopril with celery extract orally in male rats induced by $4 \% \mathrm{NaCl}$. The blood pressure was measured using a non-invasive tail method. The urine and blood were collected, and the sodium, potassium concentration, and cumulative urine volume were measured. The combination of $5 \mathrm{mg} / \mathrm{kgBW}$ of captopril and $40 \mathrm{mg} / \mathrm{kgBW}$ of celery extract decreased the blood pressure in hypertensive rats better than $5 \mathrm{mg} / \mathrm{kgBW}$ of captopril alone. The fell in blood pressure was followed by an increase in urine volume. Urinary and serum sodium, serum potassium levels tended to increase in all treatment groups, but not significantly different from the healthy group. Urinary potassium levels tended to decrease except in the combined $5 \mathrm{mg} / \mathrm{kgBW}$ of captopril and $40 \mathrm{mg} / \mathrm{kgBW}$ of celery extract. In conclusion, oral administration of a combination of 5 $\mathrm{mg} / \mathrm{kgBW}$ captopril and $40 \mathrm{mg} / \mathrm{kgBW}$ celery extract decreased the blood pressure to the standard value in $\mathrm{NaCl}$-induced hypertension rats.
\end{abstract}

Keywords: Apium graveolens, captopril, celery, hypertension, pharmacodynamic

\section{Pengaruh Pemberian Kombinasi Kaptopril dan Ekstrak Seledri pada Tekanan Darah dan Kadar Elektrolit Tikus Hipertensi}

\begin{abstract}
Abstrak
Berdasarkan penelitian sebelumnya, pemberian kombinasi kaptopril dan seledri dapat menurunkan tekanan darah pada pasien hipertensi. Penelitian ini bertujuan membuktikan adanya perubahan pada tekanan darah, volume urin, kadar natrium dan kalium dengan kombinasi kaptopril dan ekstrak seledri yang diberikan secara oral pada tikus yang diinduksi $\mathrm{NaCl} 4 \%$. Pengukuran tekanan darah secara non-invasive pada ekor. Pengambilan sampel urin dan darah untuk pengujian kadar natrium, kalium, dan volume urin dilakukan pada hari ke 46. Tekanan darah tikus yang mendapat kombinasi kaptopril dosis $5 \mathrm{mg} / \mathrm{kgBB}$ dengan ekstrak seledri dosis $40 \mathrm{mg} / \mathrm{kgBB}$ menurun lebih besar dibandingkan dengan pemberian kaptopril tunggal dosis $5 \mathrm{mg} / \mathrm{kgBB}$. Penurunan tekanan darah pada kelompok kombinasi kaptopril dan ekstrak seledri diikuti dengan peningkatan volume urin. Kadar natrium urin dan serum, serta kadar kalium serum cenderung mengalami peningkatan pada semua kelompok perlakuan namun tidak bermakna dibandingkan dengan kelompok normal. Kadar kalium urin cenderung mengalami penurunan kecuali pada kelompok kombinasi kaptopril $(5 \mathrm{mg} / \mathrm{kgBB})$ dan ekstrak seledri $(40 \mathrm{mg} /$ $\mathrm{kgBB}$ ). Dapat disimpulkan pemberian kombinasi secara oral kombinasi kaptopril dosis $5 \mathrm{mg} / \mathrm{kgBB}$ dan ekstrak seledri dosis $40 \mathrm{mg} / \mathrm{kgBB}$ menurunkan tekanan darah kembali normal pada tikus hipertensi yang diinduksi $\mathrm{NaCl}$.
\end{abstract}

Kata Kunci: Apium graveolens, farmakodinamik, hipertensi, kaptopril, seledri 


\section{Pendahuluan}

Terapi menggunakan obat herbal untuk pengobatan penyakit kardiovaskuler makin meningkat. ${ }^{1}$ Pengobatan tradisional menggunakan herbal sebagai alternatif pengobatan banyak dilakukan karena anggapan bahwa herbal lebih aman dan mudah untuk digunakan. ${ }^{2}$ Penggunaan obat herbal tidak sepenuhnya mampu menurunkan tekanan darah, sehingga masyarakat tetap menggunakan obat sintetik. ${ }^{3}$ Penggunaan bersamaan obat herbal dengan obat sintetik tidak menutup kemungkinan terjadinya interaksi. ${ }^{3}$ Efek negatif dapat timbul dari keterbatasan informasi dan pasien biasanya menggunakan obat herbal tanpa menginformasikan kepada tenaga kesehatan. ${ }^{4}$ Interaksi mungkin melibatkan komponen yang terdapat pada obat herbal yang dapat menyebabkan peningkatan atau penurunan efek dari obat sintetik bahkan menimbulkan atau meningkatkan efek samping. ${ }^{5}$

Peredaran kaptopril dan seledri yang cukup luas di masyarakat, menyebabkan kemungkinan penggunaan secara bersamaan semakin tinggi. Penelitian terkait interaksi obat konvensional dan obat herbal di 5 Puskesmas wilayah Depok, dilaporkan sebanyak 39,8\% (49 dari 123 pasien) yang sedang menggunakan obat antihipertensi juga menggunakan obat herbal, salah satunya seledri. ${ }^{6}$ Obat antihipertensi yang digunakan bersamaan dengan obat herbal sebanyak 71,4\% (35 dari 49 pasien) adalah kaptopril. ${ }^{6}$ Penelitian lain melaporkan penggunaan bersamaan kaptopril dengan seledri pada pasien hipertensi, menunjukkan penurunan tekanan darah lebih besar dibandingkan pemberian kaptopril dan seledri tunggal. ${ }^{7}$ Penelitian lain melaporkan bahwa kombinasi kaptopril dosis $5 \mathrm{mg} / \mathrm{kgBB}$ dan ekstrak seledri dosis $40 \mathrm{mg} / \mathrm{kgBB}$ yang diberikan secara oral dengan jeda waktu 1 jam meningkatkan Cmax (38,67\%), T1/2 (37,84\%), dan AUC (58,10\%) serta menurunkan Ke $(27,45 \%)$ kaptopril. ${ }^{8}$ Berdasarkan hasil penelitian terdahulu, perlu untuk dilakukan uji terhadap efek klinis yang mungkin timbul akibat pemberian kombinasi tersebut. Penelitian ini bertujuan untuk mengetahui efek kombinasi kaptopril dan ekstrak seledri pada tekanan darah, kadar natrium dan kalium pada darah dan urin tikus jantan galur Sprague-Dawley yang diinduksi hipertensi menggunakan $\mathrm{NaCl} 4 \%$.

\section{Metode}

\subsection{Alat}

Peralatan yang akan digunakan dalam penelitian ini, alat pengukur tekanan darah Coda $^{\circledR}$ Blood Pressure (Kent Scientific, Torrington, USA), Spektroklinikal Microlab 300® (Elitech Group, Logan, USA), Microplate reader iMark ${ }^{\mathrm{TM}}$ (BioRad, California, USA), dan rotari evaporator (Buchi, Darmstadt, Germany).

\subsection{Bahan}

Bahan-bahan yang digunakan dalam penelitian ini, herba seledri (Apium gravelons) didapat dari Pasar Induk Kramat Jati Jakarta Timur. Herba seledri dideterminasi di Herbarium Bogoriense Pusat Penelitian Biologi LIPI Cibinong, Jawa Barat, dengan surat determinasi no. 1777/IPH.1.01/If.07/ VIII/2016. Tikus galur SD berumur 3-4 bulan dengan berat badan berkisar 200 - $300 \mathrm{~g}$ dari Fakultas Peternakan Institut Pertanian Bogor. Kaptopril (Zhejiang Huahai Pharmaceutical, China), etanol 96\% (Merck, Darmstadt, Germany), dan $\mathrm{NaCl}$ pa (Merck, Darmstadt, Germany).

\subsection{Prosedur}

2.3.1. Penyiapan Hewan Percobaan

Hewan coba yang digunakan adalah tikus putih jantan galur Sprague-Dawley berumur 3-4 bulan dengan berat badan berkisar 200 g-300 g diperoleh dari Fakultas Peternakan, Institut Pertanian Bogor. Sebelum dikelompokkan, tikus diaklimatisasi terlebih dahulu di laboratorium percobaan selama 1 minggu. Tikus yang digunakan untuk percobaan adalah tikus yang dinilai sehat yaitu bila selama pemeliharaan bobot badan tikus tidak mengalami penurunan berarti, secara visual memperlihatkan perilaku normal dan memiliki tekanan darah sistol 100-129 $\mathrm{mmHg}$ dan diastol 70-89 $\mathrm{mgHg}$. Protokol penelitian telah mendapatkan surat keterangan lolos kaji etik No. 1276/UN2.F1/ 
ETIK/XII/2017 dari Komite Etik Penelitian Kesehatan Fakultas Kedokteran Universitas Indonesia. Pengelompokkan hewan hipertensi dapat dilihat pada Tabel 1.

\subsubsection{Ekstraksi Seledri dan Pengujian}

Fisikokimia

Simplisia yang digunakan adalah herba seledri yang diperoleh dari Pasar Induk Kramat Jati, Jakarta Timur dan dideterminasi di LIPI Cibinong dengan surat determinasi no. 1777/IPH.1.01/If.07/VIII/2016.

\subsubsection{Induksi Hewan}

Tikus yang telah diaklimatisasi diinduksi hipertensi menggunakan $\mathrm{NaCl} 4 \%$ selama 2-4 minggu, diberikan secara peroral sebanyak $1 \%$ dari berat badan setiap hari selama 3 minggu dan dilanjutkan selama penelitian berlangsung. ${ }^{9}$

\subsubsection{Uji Antihipertensi}

Hewan uji dikelompokkan menjadi beberapa kelompok dengan tiap kelompok terdiri dari 5 ekor tikus. Tikus kelompok I merupakan kontrol normal diberikan diet standar dan minuman akuades. Tikus kelompok II sampai IX diinduksi hipertensi dengan $\mathrm{NaCl} 4 \%$ selama 2 minggu dan dilanjutkan selama penelitian berlangsung. Tikus kelompok II merupakan kontrol negatif, diberikan diet standar dan larutan $\mathrm{NaCl} 4 \%$ disonde selama penelitian berlangsung.
Pemberian bahan uji kaptopril, ekstrak etanol seledri, dan kombinasi pada kelompok III sampai dengan IX dimulai pada hari ke15 sampai dengan hari ke-45. Pengukuran tekanan darah dilakukan sebanyak 3 kali yaitu sebelum perlakuan (hari ke-0), kemudian setelah induksi $\mathrm{NaCl} 4 \%$ (hari ke-15) dan setelah pemberian kaptopril dan ekstrak (hari ke-46). Pengukuran parameter tekanan darah meliputi tekanan darah sistol dan tekanan darah diastol. Pengukuran menggunakan alat Coda® Non Invasive blood presure. ${ }^{10}$ Protokol penelitian telah mendapatkan surat keterangan lolos kaji etik No. 863/UN2. F1/ETIK/2016 dari Komite Etik Penelitian Kesehatan Fakultas Kedokteran Universitas Indonesia.

\subsubsection{Pengambilan Sampel Urin dan Serum Pengambilan sampel urin dilakukan} pada hari ke-46. Tikus diletakkan di dalam kandang metabolik selama 24 jam setelah pemberian sediaan uji. Sampel urin yang terkumpul, diukur volume, kadar kalium, natrium.

Pengambilan darah dilakukan melalui sinus orbital mata pada hari ke-46. Darah yang diperoleh ditampung dalam tabung sentrifugal secara hati-hati untuk mencegah hemolisis. Pengendapan protein yang terdapat dalam darah dilakukan dengan sentrifugasi pada kecepatan $6000 \mathrm{rpm}$ selama 5 menit untuk mendapatkan filtrat yang jernih. Supernatan

Tabel 1. Pengelompokkan Hewan Hipertensi

\begin{tabular}{ccl}
\hline Kelompok & $\begin{array}{c}\text { Jumlah } \\
\text { hewan }\end{array}$ & \multicolumn{1}{c}{ Perlakuan } \\
\hline I & 5 & Kontrol normal \\
II & 5 & Kontrol negatif (induksi hipertensi tanpa bahan uji) \\
III & 5 & Kontrol positif (induksi hipertensi + kaptopril $1,25 \mathrm{mg} / \mathrm{kgBB})$ \\
IV & 5 & Kontrol positif (induksi hipertensi + kaptopril $2,5 \mathrm{mg} / \mathrm{kgBB})$ \\
V & 5 & Kontrol positif (induksi hipertensi + kaptopril $5 \mathrm{mg} / \mathrm{kgBB})$ \\
VI & 5 & Ekstrak seledri (induksi hipertensi + ekstrak seledri $40 \mathrm{mg} / \mathrm{kgBB})$ \\
VII & 5 & Kombinasi (induksi hipertensi + kombinasi kaptopril $(1,25 \mathrm{mg} / \mathrm{kgBB})$ \\
dan ekstrak seledri 40 mg/kgBB)
\end{tabular}


(serum) inilah yang akan digunakan untuk pengukuran kadar kalium dan natrium.

\subsubsection{Pengukuran Kadar Kalium}

Pengukuran kadar kalium menggunakan spektrofotometer microlab $300 \AA$ dengan menggunakan Potassium liquidrapid test Human ${ }^{\circledR}$ (Human, Magdeburg, Germany). Serum atau urin sebanyak $50 \mu \mathrm{L}$ ditambahkan $500 \mu \mathrm{L}$ asam trikloroasetat, sentrifugasi 6000 rpm selama 5 menit, akan didapatkan supernatan. Pengujian dilakukan dengan mereaksikan supernatan dengan campuran natrium tetrafenilboron dan natrium hidroksida, divorteks dan didiamkan selama 5 menit kemudian diukur pada panjang gelombang $578 \mathrm{~nm}$.

\subsubsection{Pengukuran Kadar Natrium \\ Pengukuran kadar}

natrium menggunakan spektrofotometer microlab 300® (Elitech Group, Logan, USA) dengan menggunakan Sodium rapid test Human ${ }^{\circledR}$ (Human, Magdeburg, Germany). Serum atau urin sebanyak $20 \mu \mathrm{L}$ ditambahkan campuran uranil asetat dan magnesium asetat (Prec), dibiarkan selama 5 menit kemudian divortex selama 30 detik dan dibiarkan 30 menit, selanjutnya disentrifugasi $6000 \mathrm{rpm}$ selama 5 menit, akan didapatkan supernatan. Pengujian dilakukan dengan mereaksikan supernatant dengan campuran ammonium tioglikolat dan ammonia (RGT) sebanyak $1000 \mu \mathrm{L}$, divortex.
Pengukuran dilakukan setelah 5 menit pada panjang gelombang $405 \mathrm{~nm}$.

\subsubsection{Analisa Data}

Data kuantitatif parameter tekanan darah, kadar kalium, natrium dianalisis secara statistik menggunakan ANAVA satu arah yang dilanjutkan dengan Uji Beda Nyata Terkecil dan kebermaknaan diambil pada tingkat kepercayaan $95 \%$. Semua data ditunjukkan sebagai rataan \pm Standar Deviasi (SD).

\section{Hasil}

3.1. Hasil Ekstraksi Herba Seledri

Penyiapan herba seledri dan pembuatan ekstrak menggunakan etanol 50\% dengan metode maserasi. ${ }^{8}$ Hasil ekstraksi yang didapat dilakukan pengujian organoleptik, fisikokimia, fitokimia, dan kadar apigenin. Hasil organoleptik, ekstrak berwarna hijau kecoklatan, berbau aromatik, dan berbentuk kental. Hasil uji fisikokimia didapatkan hasil kadar abu total (b/b) 6,70\% 0,628; kadar abu tidak larut asam (b/b) 2,57 \% $\pm 0,476$; kadar air (v/b) 8,89\% $\%$ 0,028; kadar minyak atsiri (v/b) 3,34 \% $\pm 0,023$; dan susut pengeringan (b/b) $4,87 \% \pm 0,2626$. Hasil uji fitokimia dan kadar apigenin ekstrak etanol 50\% seledri dapat dilihat pada Tabel 2 .

\subsection{Hasil Induksi Hipertensi dengan $\mathrm{NaCl}$ $4 \%$ \\ Metode induksi yang digunakan pada}

Tabel 2. Hasil Penapisan Fitokimia dan Pengujian Kadar Apigenin Ekstrak Etanol 50\% Herba Seledri (Apium graveolen L.)

\begin{tabular}{ccc}
\hline Golongan senyawa & Pereaksi & Keterangan \\
\hline Alkaloid & Bouchardat & - \\
& Mayer & - \\
Flavonoid & $\mathrm{Mg}+\mathrm{HCl}$ & + \\
Saponin & Tes buih & + \\
Tanin & Gelatin $10 \%$ & + \\
Triterpenoid & H2SO4 & $3,64 \%(\mathrm{~b} / \mathrm{b})$ \\
Total fenol & Spektrofotometri & $0,61 \%(\mathrm{~b} / \mathrm{b})$ \\
Total flavonoid & Spektrofotometri & $0,274 \mathrm{mg} / \mathrm{g}$ \\
Kadar apigenin & KLT densitometri &
\end{tabular}

Keterangan : $\quad(+)$ : ada

(-) : tidak ada 
penelitian ini adalah dengan pemberian $\mathrm{NaCl} 4 \%$ b/v secara oral setiap hari selama 2-3 minggu. Hasilnya tekanan darah sistol meningkat dari rerata $107,28 \mathrm{mmHg} \pm 3,36$ menjadi $138,94 \mathrm{mmHg} \pm 9,70$ dan diastol meningkat dari rerata $81,33 \mathrm{mmHg} \pm 8,77$ menjadi 104,28 $\mathrm{mmHg} \pm 11,26$.

\subsection{Hasil Pengujian Antihipertensi}

Hasil pengujian antihipertensi kombinasi kaptopril dosis $1,25 \mathrm{mg} / \mathrm{kgBB} ; 2,5$ $\mathrm{mg} / \mathrm{kgBB}$; dan $5 \mathrm{mg} / \mathrm{kgBB}$ dengan ekstrak seledri dosis $40 \mathrm{mg} / \mathrm{kgBB}$, dapat menurunkan tekanan darah tikus hipertensi yang diinduksi dengan $\mathrm{NaCl} 4 \%(\mathrm{p}<0,05)$. Penurunan tekanan darah terbesar pada kombinasi ekstrak seledri $40 \mathrm{mg} / \mathrm{kgBB}$ dengan kaptopril dosis $5 \mathrm{mg}$ / kgBB (kelompok IX). Hasil pengukuran tekanan darah sistol dan diastol dapat dilihat pada Tabel 3 dan 4.

\subsection{Hasil Pengukuran Kadar Kalium dan Natrium}

Hasil pengukuran kadar natrium dan kalium baik di dalam serum maupun urin dipengaruhi secara signifikan oleh kelompok perlakuan $(p<0,05)$. Kadar natrium serum kelompok $\mathrm{V}$ lebih rendah dibandingkan dengan kelompok I $(\mathrm{p}<0,05)$. Kelompok lainnya mengalami perubahan kadar natrium dalam serum namun tidak berbeda bermakna dengan kelompok I $(\mathrm{p}>0,05)$.

Kadar kalium serum mengalami peningkatan pada kelompok yang diberikan kaptopril dosis 2,5 mg/kgBB (IV), $5 \mathrm{mg} / \mathrm{kgBB}$ (V), dan ekstrak seledri $40 \mathrm{mg} / \mathrm{kgBB}$ (VI) jika dibandingkan dengan kelompok normal namun tidak berbeda bermakna $(\mathrm{p}>0,05)$. Data hasil pengukuran kadar kalium dan natrium dapat dilihat pada Tabel 5.

\section{Pembahasan}

Kombinasi kaptopril dengan ekstrak seledri mampu menurunkan tekanan darah pada tikus hipertensi lebih besar dibandingkan dengan pemberian tunggal masing-masing komponen. Kadar natrium dan kalium urin serta darah mengalami perubahan akibat dari kombinasi ini.

Parameter fisikokimia ekstrak berkaitan dengan standar mutu ekstrak. Parameter standar mutu ekstrak terdiri dari parameter spesifik dan parameter non spesifik. Parameter spesifik adalah aspek kandungan kimia kualitatif dan aspek kuantitatif kadar senyawa kimia yang bertanggung jawab

Tabel 3. Rerata Tekanan Darah Sistol (TDS \pm SD) sebelum perlakuan (baseline), setelah induksi (hari ke 15), dan setelah perlakuan (hari ke 26, 36, dan 46)

\begin{tabular}{ccccccc}
\hline KIp & $\begin{array}{c}\text { TDS Baseline } \\
(\mathbf{m} \text { Hg } \pm \text { SD) } \\
\text { Hari ke-0 }\end{array}$ & $\begin{array}{c}\text { TDS } \\
\text { Induksi } \\
(\mathbf{m m H g} \pm \mathbf{S D}) \\
\text { Hari ke-15 }\end{array}$ & $\begin{array}{c}\text { TDS } \\
\text { Perlakuan } \\
\text { Hari ke-26 }\end{array}$ & $\begin{array}{c}\text { TDS } \\
\text { Perlakuan } \\
\text { HmHg } \pm \text { SD) } \\
\text { Hari ke-36 }\end{array}$ & $\begin{array}{c}\text { TDS } \\
\text { Perlakuan } \\
\text { (mmHg } \pm \text { SD) } \\
\text { Hari ke-46 }\end{array}$ & $\begin{array}{c}\text { Penurunan } \\
\text { Pm }\end{array}$ \\
\hline I & $110 \pm 5,31$ & $110 \pm 4,60$ & $120 \pm 3,08$ & $109 \pm 5,52$ & $112 \pm 7,83$ & $-2,49 \pm 7,87$ \\
II & $107 \pm 5,59$ & $146 \pm 4,16$ & $144^{\mathrm{b}} \pm 3,70$ & $146 \mathrm{c} \pm 4,22$ & $148^{\mathrm{d}} \pm 5,22$ & $-1,39 \pm 3,04$ \\
III & $108 \pm 5,73$ & $140 \pm 0,55$ & $108 \pm 9,31$ & $107 \pm 2,70$ & $106 \pm 7,54$ & $24,21 \pm 5,54$ \\
IV & $109 \pm 2,74$ & $142 \pm 2,49$ & $108 \pm 8,93$ & $106 \pm 7,99$ & $101^{\mathrm{d}} \pm 4,00$ & $28,99 \pm 2,00$ \\
V & $110 \pm 2,66$ & $142 \pm 1,10$ & $110 \pm 7,40$ & $96 \pm 9,13$ & $101^{\mathrm{d}} \pm 4,00$ & $35,83 \pm 1,00$ \\
VI & $112 \pm 3,19$ & $141 \pm 1,52$ & $110 \pm 2,79$ & $108 \pm 5,98$ & $100^{\mathrm{d}} \pm 4,10$ & $29,00 \pm 2,73$ \\
VII & $109 \pm 5,28$ & $140 \pm 3,03$ & $127^{\mathrm{b}} \pm 9,66$ & $107 \pm 12,36$ & $110 \pm 2,51$ & $21,56 \pm 2,96$ \\
VIII & $112 \pm 4,02$ & $140 \pm 1,48$ & $128^{\mathrm{b}} \pm 10,55$ & $112 \pm 3,63$ & $109 \pm 5,40$ & $22,99 \pm 3,35$ \\
IX & $115 \pm 2,77$ & $142 \pm 5,18$ & $137^{\mathrm{b}} \pm 7,98$ & $102 \pm 5,24$ & $85^{\mathrm{d}} \pm 5,55$ & $42,34^{\mathrm{e}} \pm$ \\
\hline
\end{tabular}

$\mathrm{a}=\mathrm{p}<0,05$ terhadap kelompok normal TDS hari ke- 15

$\mathrm{b}=\mathrm{p}<0,05$ terhadap kelompok normal TDS hari ke-26

$\mathrm{c}=\mathrm{p}<0,05$ terhadap kelompok normal TDS hari ke-36

$\mathrm{d}=\mathrm{p}<0,05$ terhadap kelompok normal TDS hari ke-46

$\mathrm{e}=\mathrm{p}<0,05$ terhadap semua kelompok pada hari ke-46 (persen penurunan TDS) 
Tabel 4. Rerata Tekanan Darah Diastol $(\mathrm{TDD} \pm \mathrm{SD}$ ) sebelum perlakuan (baseline), setelah induksi (hari ke-15), dan setelah perlakuan (hari ke 26, 36, dan 46)

\begin{tabular}{ccccccc}
\hline Klp & $\begin{array}{c}\text { TDD Baseline } \\
(\mathbf{m m H g} \pm \text { SD) } \\
\text { Hari ke-0 }\end{array}$ & $\begin{array}{c}\text { TDD } \\
\text { Induksi } \\
(\mathbf{m m H g} \pm \text { SD) } \\
\text { Hari ke-15 }\end{array}$ & $\begin{array}{c}\text { TDD } \\
\text { Perlakuan } \\
(\mathbf{m m H g} \pm \text { SD) } \\
\text { Hari ke-26 }\end{array}$ & $\begin{array}{c}\text { TDD } \\
\text { Perlakuan } \\
(\mathbf{m m H g} \pm \text { SD }) \\
\text { Hari ke-36 }\end{array}$ & $\begin{array}{c}\text { TDD } \\
\text { Perlakuan } \\
(\mathbf{m m H g} \pm \text { SD) } \\
\text { Hari ke-46 }\end{array}$ & $\begin{array}{c}\text { \% } \\
\text { Penurunan }\end{array}$ \\
\hline I & $75 \pm 1,08$ & $73 \pm 2,35$ & $79 \pm 2,35$ & $73 \pm 4,80$ & $76 \pm 3,63$ & $-3,86 \pm 4,57$ \\
II & $75 \pm 3,81$ & $102^{\mathrm{a}} \pm 3,94$ & $101^{\mathrm{b}} \pm 2,19$ & $102^{\mathrm{c}} \pm 2,74$ & $108^{\mathrm{d}} \pm 1,92$ & $-5,82 \pm 4,77$ \\
III & $76 \pm 3,67$ & $99^{\mathrm{a}} \pm 4,22$ & $70^{\mathrm{b}} \pm 6,69$ & $73 \pm 4,80$ & $70 \pm 4,64$ & $28,89^{\mathrm{e}} \pm 5,79$ \\
IV & $76 \pm 3,24$ & $91^{\mathrm{a}} \pm 0,89$ & $69^{\mathrm{b}} \pm 8,93$ & $71 \pm 8,29$ & $68 \pm 7,86$ & $25,41^{\mathrm{e}} \pm 8,47$ \\
V & $76 \pm 3,28$ & $100^{\mathrm{a}} \pm 6,23$ & $73^{\mathrm{b}} \pm 7,92$ & $65 \pm 4,92$ & $59^{\mathrm{d}} \pm 2,35$ & $40,59^{\mathrm{e}} \pm 4,19$ \\
VI & $75 \pm 2,97$ & $93^{\mathrm{a}} \pm 1,52$ & $75^{\mathrm{b}} \pm 3,65$ & $74 \pm 5,43$ & $67 \pm 6,46$ & $27,36^{\mathrm{e}} \pm 7,73$ \\
VII & $73 \pm 3,02$ & $99^{\mathrm{a}} \pm 8,04$ & $89 \pm 9,13$ & $70 \pm 10,10$ & $71 \pm 1,22$ & $27,80^{\mathrm{e}} \pm 5,36$ \\
VIII & $79 \pm 2.17$ & $94^{\mathrm{a}} \pm 5,59$ & $89 \pm 10,18$ & $76 \pm 2,55$ & $73 \pm 5,26$ & $25,92^{\mathrm{e}} \pm 6,98$ \\
IX & $77 \pm 3,11$ & $97^{\mathrm{a}} \pm 8,76$ & $93^{\mathrm{b}} \pm 8,17$ & $64 \pm 5,41$ & $57^{\mathrm{d}} \pm 3,36$ & $42,28^{\mathrm{e}} \pm 6,57$ \\
\hline
\end{tabular}

$\mathrm{a}=\mathrm{p}<0,05$ terhadap kelompok normal TDD hari ke-15

$\mathrm{b}=\mathrm{p}<0,05$ terhadap kelompok normal TDD hari ke-26

$\mathrm{c}=\mathrm{p}<0,05$ terhadap kelompok normal TDD hari ke-36

$\mathrm{d}=\mathrm{p}<0,05$ terhadap kelompok normal TDD hari ke-46

$\mathrm{e}=\mathrm{p}<0,05$ terhadap semua kelompok pada hari ke-46 (persen penurunan TDD)

terhadap aktivitas farmakologis tertentu. ${ }^{9}$ Parameter spesifik yang diujikan adalah organoleptik esktrak dan uji kandungan kimia ekstrak. Hasil uji kandungan kimia ekstrak berdasarkan uji warna didapatkan bahwa ekstrak etanol $50 \%$ seledri mengandung flavonoid, saponin, tanin, dan triterpenoid. Hasil ini sesuai dengan penelitian sebelumnya menggunakan ekstrak etanol dan metanol. ${ }^{12}$

Hewan percobaan yang digunakan adalah tikus putih jantan berumur 3-4 bulan dengan berat badan berkisar $200 \mathrm{~g}-300 \mathrm{~g}$. Tikus diaklimatisasi sebelum digunakan. Aklimatisasi bertujuan untuk menyeragamkan perlakuan dan juga untuk membiasakan hewan pada kondisi dan perlakuan yang baru. Tikus yang digunakan adalah yang secara visual memperlihatkan perilaku normal dan memiliki tekanan darah normal berkisar antara $100 \mathrm{mmHg}-129 \mathrm{mmHg} .{ }^{10}$ Hasil perhitungan statistik menunjukkan bahwa induksi dengan $\mathrm{NaCl} 4 \%$ selama 2 minggu secara peroral dapat meningkatkan tekanan darah berbeda bermakna dengan kelompok tikus yang tidak diinduksi dengan tingkat kepercayaan 95\%. Hasil yang didapat sesuai dengan penelitian sebelumnya yang melaporkan bahwa pemberian $\mathrm{NaCl} 4 \%$ selama $14-17$ hari pada tikus jantan galur Sprague-Dawley dapat meningkatkan tekanan darah dengan mempengaruhi sistem saraf simpatis. ${ }^{13}$

Penggunaan model hewan diharapkan dapat memberikan pemahaman mengenai berbagai aspek penyakit seperti etiologi, patofisiologi, komplikasi, dan pengobatannya. Beberapa model hewan dikembangkan untuk memahami mengenai faktor etiologi yang berperan dalam terjadinya hipertensi pada manusia. Keterbatasan metode penggunaan model hewan untuk hipertensi adalah tidak adanya bukti untuk mendukung bahwa setiap model hewan pada eksperimen hipertensi menggambarkan kejadian pada manusia. Beberapa faktor yang dapat mempengaruhi hasil dalam penggunaan model hewan adalah dosis, perbedaan spesies, jenis kelamin serta umur hewan di awal paparan dan metode yang digunakan dalam pengukuran tekanan darah. $^{14}$

Hasil pengukuran tekanan darah menunjukkan semua kelompok perlakuan kecuali kelompok normal (kelompok I) dan kelompok kontrol negatif (kelompok II), mengalami penurunan tekanan darah sistol (TDS) dan diastole (TDD). TDS dan TDD kelompok IX pada hari ke-46 memiliki 
Tabel 5. Kadar Natrium dan Kalium setelah perlakuan (hari ke-46)

\begin{tabular}{ccccc}
\hline Klp & $\begin{array}{c}\text { Natrium Serum } \\
(\mathbf{m m o l} / \mathbf{L})\end{array}$ & $\begin{array}{c}\text { Natrium Urin } \\
(\mathbf{m m o l} / \mathbf{L})\end{array}$ & $\begin{array}{c}\text { Kalium Serum } \\
(\mathbf{m m o l} / \mathbf{L})\end{array}$ & $\begin{array}{c}\text { Kalium Urin } \\
(\mathbf{m m o l} / \mathbf{L})\end{array}$ \\
\hline I & $61,72 \pm 5,210$ & $166,59 \pm 4,548$ & $4,18 \pm 0.466$ & $49,58 \pm 19,722$ \\
II & $50,94 \pm 4,597$ & $126,12^{*} \pm 1,758$ & $4,12 \pm 0,517$ & $10,4^{*} \pm 1,398$ \\
III & $52,92 \pm 4,778$ & $173,02 \pm 5,167$ & $3,72 \pm 0,327$ & $16,38^{*} \pm 8,060$ \\
IV & $50,24 \pm 5,541$ & $208,18 \pm 8,097$ & $4,78 \pm 1,105$ & $23,42^{*} \pm 5,444$ \\
V & $44,26^{*} \pm 14,885$ & $240,84^{*} \pm 8,953$ & $5,02 \pm 0,377$ & $25,05^{*} \pm 20,764$ \\
VI & $66 \pm 11,970$ & $201,02 \pm 8,824$ & $5,46 \pm 0,439$ & $11,3^{*} \pm 1,502$ \\
VII & $63,24 \pm 2,654$ & $134,1^{*} \pm 35,639$ & $3,56 \pm 0,397$ & $17,31^{*} \pm 9,878$ \\
VIII & $54,56 \pm 6,286$ & $355,20^{*} \pm 8,717$ & $4,48 \pm 0,712$ & $31,54^{*} \pm 6,723$ \\
IX & $54,70 \pm 6,306$ & $360,72^{*} \pm 5,632$ & $3,58 \pm 0,164$ & $52,14 \pm 2,407$ \\
\hline
\end{tabular}

*Berbeda bermakna dibandingkan dengan kelompok normal pada hari ke-46 $(\mathrm{p}<0,05)$

tekanan darah yang lebih rendah jika dibandingkan dengan kelompok normal. TDS dan TDD kelompok IX, berturut-turut turun sebesar $42,34 \% \pm 3,61$ dan $42,28 \% \pm 6,57$ dari nilai TDS pada saat setelah diinduksi (hari ke-15). Hasil ini menunjukkan bahwa pemberian kaptopril, ekstrak seledri, dan kombinasi kaptopril dengan ekstrak seledri dapat menurunkan tekanan darah tikus hipertensi yang diinduksi dengan $\mathrm{NaCl} 4 \%$. Penurunan tekanan darah terbesar yaitu pada pemberian kombinasi kaptopril dosis $5 \mathrm{mg} / \mathrm{kgBB}$ dengan ekstrak seledri dosis $40 \mathrm{mg} / \mathrm{kgBB}$ dan efeknya lebih baik jika dibandingkan dengan pemberian kaptopril dan ekstrak seledri tunggal dengan dosis yang sama. Pemberian kombinasi kaptopril dengan ekstrak Seledri mulai menurunkan tekanan darah sebanding dengan kelompok normal pada hari ke-20 setelah pemberian kombinasi. Hal ini mungkin disebabkan terjadinya penghambatan absorpsi kaptopril pada pemberian awal kombinasi kaptopril dengan ekstrak seledri sehingga menurunkan kadar obat di dalam tubuh yang mempengaruhi efektivitas kerja kaptopril. ${ }^{15}$

Kaptopril merupakan penghambat enzim konversi angiotensin yang pertama ditemukan dan banyak digunakan di klinik untuk pengobatan hipertensi ringan sampai berat dan efektif untuk menangani krisis hipertensi. ${ }^{16}$ Enzim konversi angiotensin berperan dalam merubah angiotensin I menjadi angiotensin II. Angiotensin II merupakan vasokonstriktor yang kuat, mampu meningkatkan tekanan darah dan menyebabkan pelepasan radikal bebas superoksid melalui sistem NADH/NADP oksidase sehingga menurunkan konsentrasi nitrit oksida (NO) dan berakibat menurunnya respon relaksasi endotelium. ${ }^{17}$

Penelitian terdahulu melaporkan bahwa pemberian suplemen yang mengandung flavonoid kemungkinan dapat meningkatkan sintesis endotelial nitrit oksida (eNOS), sehingga dapat meningkatkan bioavailabilitas NO. ${ }^{17}$ Seledri merupakan sumber flavonoid diantaranya apigenin, luteolin, dan crysoeriol. Apigenin dan luteolin dilaporkan memiliki kemampuan meningkatkan produksi NO dengan mengaktivasi gen ekspresi mRNA eNOS, sehingga dapat merelaksasi pembuluh darah. ${ }^{17}$ Luteolin juga dapat menginduksi vasorelaksasi pada pembuluh darah aorta. ${ }^{16}$ Mekanisme tersebut memungkinkan kaptopril dan seledri bekerja sinergis dalam menurunkan tekanan darah.

Ekskresi natrium kelompok II mengalami penurunan jika dibandingkan dengan kelompok lain. Menurut Fujita dan Ando (2004) respon perubahan tekanan darah karena asupan garam dapat dikelompokkan menjadi dua yaitu kelompok salt-sensitive dan kelompok non-salt-sensitive. Peningkatan 
asupan garam menyebabkan penurunan ekskresi natrium urin pada kelompok saltsensitive. ${ }^{18}$ Ekskresi natrium semua kelompok perlakuan mengalami peningkatan jika dibandingkan kelompok normal. Peningkatan ekskresi natrium (natriuresis) merupakan mekanisme untuk menurunkan tekanan darah arteri kembali normal. Natriuresis dapat menyebabkan penurunan pada volume cairan ekstraseluler sehingga dapat menurunkan tekanan darah. ${ }^{18}$ Hasil ini sejalan dengan penelitian terdahulu yang melaporkan bahwa peningkatan ekskresi urin diikuti dengan meningkatnya ekskresi natrium. ${ }^{19}$

Ekskresi kalium pada kelompok kombinasi kaptopril dengan ekstrak seledri cenderung mengalami peningkatan jika dibandingkan dengan kelompok kaptopril tunggal. Ekskresi kalium kelompok kombinasi kaptopril dosis $5 \mathrm{mg} / \mathrm{kgBB}$ dengan ekstrak seledri dosis $40 \mathrm{mg} / \mathrm{kgBB}$ (IX) sebanding dengan kelompok normal ( $>0,050)$. Penurunan ekskresi kalium pada kelompok kontrol positif (kaptopril) dapat disebabkan karena terjadinya penurunan aldosteron ${ }^{20}$ yang berfungsi mengatur konsentrasi kalium dalam tubuh. Penurunan aldosteron disebabkan karena penghambatan dari enzim konversi angiotensin, sehingga dapat menyebabkan terjadinya hiperkalemia. ${ }^{21}$ Kecenderungan meningkatnya ekskresi kalium dapat disebabkan kemampuan ekstrak seledri sebagai diuretik. ${ }^{22}$ sehingga pengeluaran elektrolit juga akan lebih banyak sehingga dapat mengurangi risiko terjadinya hiperkalemia.

Kombinasi kaptopril dan ekstrak seledri mampu menurunkan tekanan darah sebesar 42,34\%, lebih baik dari pemberian kaptopril tunggal dan tekanan darah lebih rendah dari tikus normal $(p<0,050)$. Berdasarkan hasil penelitian ini, kombinasi kaptopril dan ekstrak seledri mampu menurunkan tekanan darah dengan cara diuresis, natriuresis dan vasorelaksasi pada pembuluh darah. Selain itu uji farmakokinetik menunjukkan bahwa terjadi peningkatan kadar kaptopril dalam plasma dan waktu paruh lebih panjang jika kaptopril diberikan bersamaan dengan ekstrak seledri pada selang waktu 1 jam. ${ }^{8}$
Penelitian ini terbatas pada pengujian efek farmakodinamik dengan menggunakan hewan model tikus sehingga belum dapat dipastikan mekanisme kerja yang spesifik dari kombinasi kaptopril dan ekstrak seledri dalam menurunkan tekanan darah.

\section{Simpulan}

Kesimpulan dari hasil penelitian ini adalah penurunan tekanan darah tikus yang mendapat kombinasi kaptopril dosis $5 \mathrm{mg} /$ $\mathrm{kgBB}$ dengan ekstrak seledri $40 \mathrm{mg} / \mathrm{kgBB}$ lebih besar dibandingkan dengan pemberian tunggal masing-masing komponen dan lebih rendah daripada tekanan darah kelompok tikus normal. Kadar natrium urin dan serum, serta kadar kalium serum cenderung mengalami peningkatan pada semua kelompok perlakuan namun tidak berbeda bermakna dengan kelompok normal $(p>0,05)$. Kadar kalium urin cenderung mengalami peningkatan terutama pada kelompok kombinasi kaptopril (5 mg/kgBB) dan ekstrak seledri (40 mg/ $\mathrm{kgBB}$ ) sebanding dengan kelompok normal $(\mathrm{p}>0,05)$.

\section{Daftar Pustaka}

1. Anwar, MA., Al Disi, SS., Eid, AH. Anti-hypertensive herbs and their mechanisms of action: part II. Frontiers in Pharmacology, 2016;7:50.

2. Qidwai, W.,Ashfaq, T. Role of garlic usage in cardiovascular disease prevention: an evidence-based approach. EvidenceBased Complementary and Alternative Medicine, 2013.

3. He, ZX., Thach, C., Zhou, SF. Clinical herb-drug interactions as a safety concern in pharmacotherapy. J. Pharmacol. Drug. Metab, 2014;1:1-3.

4. Izzo, AA., Hoon-Kim, S., Radhakrishnan, R., Williamson, EM. A critical approach to evaluating clinical efficacy, adverse events and drug interactions of herbal remedies. Phytotherapy Research, 2016;30(5):691-700.

5. Posadzki, P., Watson, L., Ernst, E. Herb-drug interactions: an overview of systematic reviews. British journal of clinical pharmacology, 2013;75(3):603- 
618.

6. Gusmira, S. Evaluasi penggunaan antihipertensi konvensional dan kombinasi konvensional bahan alam pada pasien hipertensi di Puskesmas Wilayah Depok. Makara Kesehatan, 2012;16(2):77-83.

7. Irawati. Pengaruh kombinasi kaptopril dan seledri (Apium graveolens) terhadap penurunan tekanan darah pasien hipertensi primer di wilayah kerja Puskesmas Bajoe Kabupaten Bone Tahun 2013. Universitas Hasanuddin, Makasar: Tesis. 2013.

8. Siska S, Munim A, Bahtiar A, Suyatna FD. Effect of Apium graveolens Extract Administration on the Pharmacokinetics of Captopril in the Plasma of Rats. Scientia pharmaceutica. 2018;86(1):6.

9. Kaur M., Rana AC., Kumar S. Induction of hypertension by various animal models. International Journal of Pharmacy and Biological Sciences. 2011;1(3):335-340.

10. Kent Scientific Corporation. Technical manual Coda multi-channel, computerized, non-invasive blood pressure system for mice and rats. Connecticut. 2008

11. Departemen Kesehatan Republik Indonesia. Parameter standar umum ekstrak tumbuhan obat. Jakarta: Direktorat Jendral POM Depkes RI. 2000

12. Ud Din, Z., Shad, AA., Bakht, J., Ullah, I., Jan, S. In vitro antimicrobial, antioxidant activity and phytochemical screening of Apium graveolens. Pakistan journal of pharmaceutical sciences, 2015;28(5).

13. Simmonds, SS., Lay, J., Stocker, SD. Dietary salt intake exaggerates sympathetic reflexes and increases blood pressure variability in normotensive rats. Hypertension. 2014; 114.

14. Leong, XF., Ng, CY., Jaarin, K. Animal models in cardiovascular research: hypertension and atherosclerosis. BioMed research international. 2015.
15. Katzung BG., Masters SB., Trevor AJ. Basic \& clinical pharmacology. San Francisco: Mc Grew Hill Companies Inc; 2015:169-271.

16. Kaya, A., Tatlisu, MA., Kaya, TK., Yildirimturk, O., Gungor, B., Karatas, B., et al. Sublingual vs. oral captopril in hypertensive crisis. The Journal of emergency medicine, 2016;50(1), 108115.

17. Kim, JY., Kim, D., Kwon, O. Effective screening for the anti-hypertensive of selected herbs used in the traditional Korean medicines. Applied Biological Chemistry, 2016;59(4), 525-532.

18. Ando K, Fujita T. Pathophysiology of salt sensitivity hypertension. Annals of medicine. 2012;1;44(sup1):S119-26.

19. Rehman, A., Ishaq, H., Furqan, M., Sheikh, D., Raza, ML., Naqvi, BS., Mehmood, T. Comparative study of ethanolic and aqueous extracts of Apium graveolens L root with furosemide for its diuretic activity \& extraction of urinary metabolites in Wistar rats. Science International (Lahore), 2016;28:25032507.

20. Choi JG, Eom SM, Kim J, Kim SH, Huh E, Kim H, Oh MS. A comprehensive review of recent studies on herb-drug interaction: a focus on pharmacodynamic interaction. The Journal of Alternative and Complementary Medicine, 2016;22(4):262-279.

21. Hall, JE. Guyton and Hall textbook of medical physiology e-Book. Elsevier Health Sciences. 2015:371-384

22. Rouhi-Boroujeni, H., Rouhi-Boroujeni, H., Khoddami, M., Khazraei, HR., Dehkordil, EB., Rafieian-Kopaei, M. Hypolipidemic herbals with diuretic effects: A systematic review. In Biol. Sci; 2017; 8:21-28. 